\title{
SLOVENSKO-CHORVÁTSKE VZŤAHY SPRED A POČAS REVOLÚCIE 1848/1849
}

\author{
TOMÁŠ MÓRI
}

MÓRI, Tomáš: Slovak-Croatian Relations Before and During the 1848/1849 Revolution, 2019, Vol. 1, Issue 1, pp. 118 - 126. DOI: 10.17846/CEV.2019.01.1.118-126.

\begin{abstract}
The contacts of the Slavic nations during the Revolution were the culmination of their emancipation process, the search for allies in the struggles of political power for the preservation and development of their own cultures, the first Slovak national movement to cooperate with the Croatian revivalist movement. The two movements have strengthened cultural contacts and cooperation for common national goals before the revolution. The culmination of these efforts was military co-operation during the Revolution of 1848/1849. The text attempts a modest contribution to the topic in Slovak historiography and literary science. Cooperation between Slovaks and Croatians shows different political, cultural relations within the Hungarian Kingdom.
\end{abstract}

KEYWORDS: National Movements. Slovaks. Croats. Hungarian Kingdom. Revolution 1848/1849.

Revolučné obdobie rokov 1848/1849 bolo pre Slovákov prvým emancipačným pokusom zaradit sa k moderným európskym národom, ktoré sa formovali od konca 18. storočia. Na naplnenie ambícií ako politických, tak aj národných, Slováci potrebovali spojencov, ktorí zdielali rovnaké alebo podobné túžby. Obdobie prvej polovice 19. storočia bolo obdobím, ked’ sa do popredia dostávali ideológie ako pangermanizmus a panslavizmus, ktoré formovali politický pohlad jednotlivých národov Habsburskej monarchie. Málo známym faktom na Slovensku ostáva vztah Slovákov a Chorvátov, dvoch slovanských národov, ktoré zdielali spoločnú históriu od roku 1102. ${ }^{1}$ Spoločné osudy oboch národov sa stretávali a vzd’alovali v priebehu dejín, avšak v klúčových okamihoch ohrozenia našli Slováci a Chorváti spoločnú cestu prospešnú pre oba národy. Bednárová (2012, 13) uvádza: „Národnozjednocovacie tendencie sa objavovali už od posledných dekád 18. storočia. Najskôr ako osvietenský hlad po vzdelaní, pričom sa začala uplatňovat výučba v živých jazykoch, potom ako romantická potreba služby duchovnému ideálu. Túžba po etnickej sebaidentifikácii v prvej polovici 19. storočia stimulovala hladanie vnútorných väzieb a duchovnej prepojenosti etnika. “Fenomén kolektívneho myslenia psychiky môžeme aplikovat aj na slovenské a aj chorvátske národné hnutia, avšak každé národné hnutie má svoje špecifiká, z ktorých vystupujú jednotlivé odlišnosti založené na historickej minulosti a rozvinutosti kultúrnych elít. „Podla českého antropológa Iva T. Budila asimilácia archetypálnych symbolov v ideológii umožňuje transformáciu psychickej energie a jej uvolnenie na úrovni vedomia, s čím je úzko spojený proces individualizácie etnického spoločenstva. Spoločenstvo prechádza premenami, počas ktorých integruje do svojho spoločenského života prejavy jednotlivých archetypov. Mytologické pozadie sa črtá aj pri štúdiu a výskume ilýrskeho hnutia. Ideovou bázou ilyrizmu bol mýtus južnoslovanskej jednoty. Z neho ilýrci vychádzali a oň sa opierali“" (Bednárová 2012, 13).

Ako píše Krajčovič $(2010,19)$ : „Slovensko vdaka surovinovej základni patrilo k priemyselne najviac rozvíjajúcim sa oblastiam Uhorska. Táto situácia podmienila i relatívne včasné systémové vystúpenie inteligencie a sformulovanie slovenskej národnoemancipačnej platformy už v 18. storočí. Bernolákov pokus o uzákonenie spisovnej slovenčiny a národnoidentifikačnými názormi bolo synchrónne s počiatkami mad’arského a českého národného obrodenia (Krajčovič 2010).

\footnotetext{
Chorvátsko vstúpilo v roku 1102 do personálnej únie s Uhorským královstvom a v tomto spojení pretrvalo až do rozpadu Habsburskej monarchie v roku 1918.
} 
Vdaka tomu i myšlienky slovanskej vzájomnosti našli ohlas u slovenskej inteligencie, a tak bola formovaná myšlienkami slovanskej vzájomnosti a nemeckým romantizmom. Prední predstavitelia boli P. J. Šafárik v Novom Sade a J. Kollár v Pešti. Národnoemancipačné vzopätie nebolo špecifikom len stredoeurópskeho priestoru, povstanie v Belgicku v auguste 1830 vyústilo do nezávislosti krajiny, v novembri povstala pol’ská šlachta. Na Balkáne sa Srbi postupne vymaňovali spod Osmanskej okupácie ${ }^{2}$, Rumuni taktiež povstali proti Osmanom, čo znamenalo prelom v rumunskom národnom povedomí. ${ }^{3}$ Za počiatok obrodeneckých myšlienok v Chorvátsku môžeme pokladat' Ilýrske hnutie ${ }^{4}$, ktoré rozvíja predovšetkým ideológ Ljudevit Gaj ${ }^{5}$ a básnik P. Preradović. ${ }^{6}$ Základom pre ilýrske hnutie je Kollárova koncepcia štvorkmeňového slovanského národa.7 Sám Kollár píše: „Nie príliš učený, ale predsa aspoň na prvom stupni vzdelania a osvety stojaci Slovan má poznat štyri teraz žijúce vzdelanejšie nárečia, v ktorých sa píšu a tlačia knihy, a to ruské, ilýrske, pol’ské a československé“(Kollár 2009, 315). Ako však vieme, štúrovská generácia sa neskôr dištancovala od tohto Kollárovho rozdelenia slovanských jazykov a presadzovala samostatný slovenský spisovný jazyk.

Ako predkladá Krajčovič: „Proces obrodenia, formovania sa novodobých národov nebol motivovaný len subjektívnymi faktormi, nadšením obrodencov. Zmeny v štruktúre spoločnosti utvárali sociálnu bázu obrodeneckých národných hnutí. Riešenie národnostnej otázky však komplikoval najmä mad’arizačný zákon z roku 1844“ (Krajčovič 2010, 23). Madarské národné hnutie samo bojovalo proti germanizácii ${ }^{8}$, avšak ideológia mad’arského hnutia bola založená na potláčaní práv nemadarských národov. V Uhorskom sneme proti madarizácii a násilnej asimilácii vystupovali predovšetkým Chorváti. Ako uvádza Krajčovič: „Kušević v roku 1826 navrhoval riešenie rečovej a národnostnej otázky po vzore Švajčiarska a USA“ (Krajčovič 2010, 23). Analogický obranný charakter obrodeneckého hnutia Slovákov a Chorvátov, ktorý bol odozvou na madarizačnú hrozbu, vytvára popri slovanskej vzájomnosti v histórii kontinuitných súvislostí a nadväzností v komparatívnom pohlade týchto vztahov. Podla Kučeru: „Slováci, podobne ako Chorváti, až do konca 18. storočia nemali ustálený vlastný spisovný jazyk. Latinčina, nemčina, či madarčina, ktoré sa uplatňovali $\mathrm{v}$ administratíve, nemohli spĺn̆at funkciu komunikatívneho celospoločenského jazyka“ (Kučera 2013, 213). Dôležitú úlohu vo formovaní vzájomných vztahov zohralo zoskupenie okolo Josefa Jungmanna, Josefa Dobrovského a Slovákov Jána Kollára a Pavla Jozefa Šafárika. Vybudovalo a ideologicky spracovalo koncepciu idey slovanskej vzájomnosti ako spoločenského hnutia na rozvoj moderných slovanských národov. Naproti tomu u južných Slovanov tzv. Ilýrske hnutie $^{9}$ (Chorvát Lj. Gaj, Slovinec B. Kopitar a Srb Vuk Karađić) sa snažilo vybudovat jednotný

\footnotetext{
Prvé sedliacke povstanie 1804 - 1812 a druhé sedliacke povstanie v Srbsku 1815.

1821 povstanie $\mathrm{v}$ Rumunsku.

4 Ilýrske hnutie - hnutie u južných Slovanov, ktoré sa zaoberalo myšlienkou zjednotenia juhoslovanských národov.

$5 \quad$ Ljudevit Gaj - chorvátsky jazykovedec, redaktor, politik a ideológ.

6 Petar Preradović - chorvátsky básnik a generál srbského pôvodu.

7 Vtedajšiu koncepciu tvorila predovšetkým unitaristická slovanská idea - československá a ilýrska koncepcia.

8 Snaha Jozefa II. centralizovat byrokratický aparát v Monarchii na základe úradného jazyka - nemčiny.

$9 \quad$ Pri pohlade na ilýrske hnutie a jeho ideologické črty vidíme črtu, ktorá je takpovediac charakteristická pre všetky národnoemancipačné hnutia v strednej a východnej Európe. Bednárová o tom píše takto: „Ilyrizmus bol koncipovaný a predstavovaný ako vnútorne pravdivý, a tým oprávnený fenomén, ktorý nemá byt považovaný len za kultúrno-politický konštrukt svojej doby, kedže má svoje hlboké korene už v mytológii. Tomu zodpovedala symbolika hnutia, ako aj špecifické formy správania jeho súčasníkov. Ilýrsku ideológiu charakterizovalo množstvo symbolov: Zornička, Mesiac, kvety, záhrada, lýra a dảšie.“
} 
juhoslovanský jazyk. ${ }^{10} \mathrm{~V}$ nadväznosti na Ilýrske hnutie je potrebné poukázat' na pojmy vo vztahoch Slovan - Chorvát, Slovan - Ilýr a Ilýr - Chorvát. Ako píše Bednárová vo svojej monografickej práci Symboly a mýty chorvátskeho národného obrodenia: „Slovanské hnutia v habsburskej monarchii sa orientovali na spoločnú medzislovanskú vzájomnú kultúrnu spoluprácu a paralelne s tým si vymedzovali vlastnú cestu k modernému nacionálnemu vývinu. Chorvátov podrobne rozpracoval chorvátsky historik Petar Korunić, ktorý rozlišuje dva základné typy. Prvý bol spojený $\mathrm{s}$ vierou v jednotu slovanského pôvodu v minulosti, zdôrazňovala sa príbuznost' jazyka, obyčajov, zvykového práva, mytológie, pričom dôležitým faktom pre vzdelancov bolo, že viac-menej etnicky homogénne vnímali ich etnikum i cudzinci. Druhým typom všeslovanskej identity Chorvátov podla Korunića bolo, že sa síce s mnohotvárnym obsahom šíril už od prelomu 15. a 16. storočia až do 20. storočia, ale jeho tri základné body zostávali vždy identické: v prvom rade išlo o súdobé argumenty, že slovanská jednota existovala už od dávnoveku a mala spoločný jazykový, etnický kultúrny a náboženský základ“ (Bednárová 2012,22). V chorvátskej spoločnosti koexistovali dve tendencie $\mathrm{v}$ jazykovej otázke, integračný (ilyrizmus) a dezintegračný (samostatný chorvátsky jazyk). Bednárová taktiež predkladá názor ohladom absencie terminologickej dôslednosti v Ilýrskom hnutí: „Väčšina nacionálnych pojmov sa nevyhla sémantickej elasticite. Preto nebola zámena termínov chorvatizmus - ilyrizmus - slovanstvo v spoločenskej praxi ojedinelým javom. V dôsledku toho vznikala i pojmová heterogenita v bežných praktických činnostiach, napr. ked' sa chorvátski študenti zapisovali na európske univerzity nie ako ,Croata', ale ako ,Illyricus', resp. ,Slavus. Táto nejednotnost’ však bola v dobovom kontexte zanedbatelná, pretože spomínané názvy sa nechápali až tak rigorózne. Podobne ani pojem ,národ' sa v ilyrskej spisbe neaplikoval dôsledne. Niekedy sa pre jednotlivé južnoslovanské etniká používali pojmy ,národ' i ,národnost‘. Terminologická konzekventnost' rozhodne absentovala“ (Bednárová 2012, 23).

V predkladanom texte sa primárne venujeme ilýrskemu hnutiu a jeho kontaktom so slovenským prostredím. Vzájomné súvislosti napomohli pri formovaní nacionalistických ideológií a práve $\mathrm{v}$ chorvátskom hnutí to bol rozmach ilýrskeho hnutia v 30. rokoch 19. storočia. V roku 1836 predložil verejnosti program Ljudevit Gaj. Ako uvádza Jelčić: „V rámci národného oživenia Chorvátska, je národné oživenie podmienené dvoma rovnakými zložkami: kultúrnymi a politickými. Je tažké povedat', ktorá zložka je prevládajúca a základná, pretože obe sú založené na vzájomnom vztahu"11 (Jelčić 2002, 14). Juhoslovanská idea v ilýrskom hnutí bola prejavom snáh o rozšírenie trhu. Tendencie prechodu od feudálnej k občianskej spoločnosti sa odrazili i v tom, že úradnícke miesta boli prístupné i nešlachticom. Už v začiatkoch Gajových vystúpení v roku 1835 Štúr z Prešporku atestoval pevné spojenia s Chorvátmi. Chorvátsky výskum prízvukuje ${ }^{12}$, že zásadný vplyv v prehistórii ilýrizmu v obrodeneckom procese u Chorvátov vôbec mali obranárske brožúry slovenských vzdelancov, ktoré vydávali u južných Slovanov. Zo všetkých môžeme menovat prácu J. Rohoňa vydanú v roku 1832 alebo brožúru M. Kuniša vydanú v Záhrebe roku

10 V bývalej Juhoslávii bola hlavným jazykom srbochorvátčina, ktorou sa hovorilo v republikách Bosna a Hercegovina, Čierna Hora, Chorvátsko a Srbsko. Spisovný srbochorvátsky jazyk mal dva varianty: srbský a chorvátsky. Rozdiely medzi nimi sa týkajú fonetiky. Po rozpade Juhoslávie v rokoch 1991 - 1995 a zvyšku Juhoslávie roku 2003 vznikli štyri krajiny s vlastnými spisovnými jazykmi, pričom bosniančina, čiernohorčina a chorvátčina sa usilujú čo najviac odlíšit od srbčiny. Srbochorvátčina sa v súčasnosti pokladá za umelý výtvor, ktorý bol konštruovaný ako politická ideológia „juhoslovanstva“ predovšetkým v 19. a 20. storočí.

11 U hrvatskoj narodnom preporodu prepleću se, međusobno uvjetuju i pounjavaju dvije ravnopravne komponente: kulturna i politička. Teško je reći koje je od njih pretežijna i osnovnija, jer se jedna na drugoj temelji i jedna drugu nadgrađuje.

12 Moguš, Milan, 2009. Povijest hrvatskoga književnoga jezika. Zagreb: Nakladni zavod Globus, 151 - 169. 
1833. Cielavedomejšiu organizáciu spolupráce národne emancipačných úsilí predstavovali spolky a mládežnícke spoločnosti. Na základe nových výskumov možno dodat', že nešlo iba o kontakty a súčinnost̉ dvoch spolkov študentskej mládeže (bratislavskej a záhrebskej) ${ }^{13}$, ale treba k nim pripočítat aj styky s centrálnym katolíckym seminárom v Pešti, ak už nezdôrazňujeme kontakty študentských spoločností v Levoči a Trnave s chorvátskymi študentmi (Krajčovič 2010). V politickej rovine štúrovci utužujú kontakty s chorvátskymi vyslancami pri uhorskom sneme, najmä s ich mladými tajomníkmi. Aby sme lepšie poukázali na nadštandardné vztahy Slovákov a Chorvátov, môžem spomenút Ljudevíta Gaja a jeho časopis Danica, kde bolo publikovaných viac slovenských materiálov ako slovinských a českých. To poukazuje na spoločné politické a kultúrne ciele, kedže v období 30. rokov a začiatkom 40. rokov narastá tendencia madarských politických elít tlačit na nemad’arské národy, aby prijali mad’arčinu za svoj politický a neskôr aj kultúrny jazyk. Tieto konflikty sa dotkli aj snemov, ktoré zasadali v Prešporku. V roku 1836 prijal snem zákony, týkajúce sa postavenia madarského jazyka, ked' ukladal za povinnost’ vyhlasovat snemové zákony v madarčine, pričom madarské znenie bolo pokladané za úradné. Hodnoverné potvrdenia dokumentov mali úvod aj záver $\mathrm{v}$ mad’arskom jazyku, aj ked' pôvodne boli písané v latinčine. Zákon taktiež ukladal povinnost̉ viest’ matriky v mad’arskom jazyku. Za medzník v predrevolučnom dianí môžeme pokladał začiatok vydávania snemového časopisu Lajosom Kossuthom Országgyulési tudósitások (Snemové správy, 1832). Ani sám Kossuth nepredpokladal tak vel'ký dopad týchto ručne písaných novín na uhorskú spoločnost'. Rýchla expanzia časopisu po Uhorsku mala za následok prebúdzanie sa občianskej spoločnosti. Snem v Bratislave v rokoch 1832 - 1836 predstavoval pomalý posun k myšlienkam liberálnej spoločnosti v duchu ideí Széchenyiho. Napríklad môžeme menovat požiadavky na výkup z dedičného poddanstva, rovnaké majetkové práva a rovnost’ pred zákonom. Prekážku voči reformnému hnutiu predstavoval knieža Metternich, ktorý videl v silnejúcom vplyve myšlienok francúzskej revolúcie problém. Pokrokové myšlienky sa snažil rázne zastavit’ a použil voči ich predstavitelom razantné kroky. Vo väzení sa tak ocitli napríklad Lászlo Lovassy a další predstavitelia snemovej mládeže. Ako dôsledok uväznenia snemovej mládeže sa v opozičnom liberálnom hnutí dostali do popredia umiernenejší politici s vodcom Ferencom Deákom. Umiernenej opozícii sa podarilo uskutočňovat’ reformy prijatelné aj pre Viedeň. Postupné odbúravanie feudálnych obmedzení v oblasti priemyselného a finančného prostredia napomáhali Uhorsku pomaly rozbiehat’ tak potrebnú industrializáciu, ktorá výrazne zaostávala za rakúskou častou monarchie. Dôležité je taktiež zmienit’ otázku príbuznosti slovenského a juhoslovansko-chorvátskeho romantizmu. Vo vedeckej práci Zlatka Klátika $(1965,65)$ Štúrovci a Juhoslovania predkladá: „Špecifickým znakom slovenského a juhoslovanského romantického hnutia je zápas o národnú a demokratickú kultúru, úsilie o vytvorenie literatúry v národnom jazyku i celej kultúry v národnom jazyku, ktorým hovorili najširšie ludové vrstvy. Takáto špecifická úloha nestála pred západným romantickým hnutím, ale ani pred ostatnými slovanskými národmi, ktoré mali dlhú literárnu tradíciu v národnom jazyku (Česi, Poliaci, Rusi). Pre oba romantizmy je zákonité, že sa formujú v úplne novom spisovnom jazyku, ktorého základom sa stalo ludové nárečie, stojace v centre národného etnika, a preto v každom jednotlivom národe najrozšírenejšie a najčistejšie. V oboch prípadoch jazykové boje sprevádzajú literárny a kultúrny život a niekedy zatláčajú do úzadia ostatné oblasti." Ako príklad môžeme uviest', že v slovenskom prostredí po pár rokoch zápasu zvítazila idea spisovnej slovenčiny nad češtinou, aj ked’ ešte pretrvávali pokusy o jej návrat. V chorvátskom prostredí tento zápas prebehol najrýchlejšie, aj ked’ tam sa zápas neviedol ani tak o jazyk, ale skôr o podobu pravopisu, čo odvádzalo pozornost’ od naliehavejších problémov.

13 Butorac, Josip, 1929 - 1930. Patriotske veze hrvatskog i slovačkog djaštva u prošlosti. In: Luć, 25, $186-188$. 
Reciprocita dosahuje zenit ešte pred kulmináciou slovenského národného obrodenia (1843 1848). Toto súhrnné hodnotenie je logickou dedukciou vyplývajúcou $\mathrm{z}$ historického konfliktu novosformulovanej štúrovskej koncepcie slovenskej samobytnosti s ilýrskym svetonázorom, vychádzajúcim z utopickej slovanskej idey. Ideový konflikt, ktorý vo vztahoch vrcholí v roku 1843, však bol konflikt dočasný a za postupnej transformácie ilýrskej ideológie v rokoch 1845 - 1848 do kroatizmu sa prejavuje súbežnost̉ nových ideológií obrodenia oboch národov (Krajčovič 2010). Ako uvádza Jelčić: „Počas toho, ako sa Chorvátsko zaoberalo ilýrstvom v susedných slovanských krajinách, s ktorými počítalo v ilýrskom hnutí, idea nenašla úspech. Od Slovincov sa pridal k idei jedine Stanko Vraz, za čo ho slovinskí národovci odsúdili, dokonca sám Prešeren. A pre Srbov už idea ilýrizmu nebola aktuálna"14 (Jelčić 2002, 41). Ako písal Jelčić, ilýrske hnutie nezískalo potrebnú podporu u ostatných juhoslovanských národov.

Mnohonárodnostná monarchia sa v čase revolúcie dostala do hlbokej krízy, bola postihnutá sociálnymi a politickými problémami. Dôsledkom kompromisného oslobodenia poddaných za náhradu a len čiastočnej likvidácie poddanských pomerov sú rol’nícke nepokoje. Delegácia madarského stavovského snemu začiatkom marca 1848 získala od viedenskej kamarily prestrašenej $\mathrm{z}$ revolučného hnutia más velké ústupky. Získanie samostatného ministerstva bolo ouvertúrou madarskej revolúcie. Kontakty medzi slovanskými národmi boli aktívne aj počas revolúcie. 20. 4. 1848 pricestoval L'udovít Štúr do Prahy. Slovenskej reprezentácii sa pred medzinárodným fórom na zjazde podarilo prezentovat slovenskú otázku. V Prahe sa uplatnil český a chorvátsky austroslavizmus ${ }^{15}$ ako platforma d’alšej slovanskej politiky. Subjektívnym cielom austroslavizmu bolo vybojovat rovnoprávnost̉ rakúskych národov, a to federalizáciou. Závažným momentom, podmieňujúcim jeho opodstatnenost', bola i hrozba vyplývajúca $\mathrm{z}$ hnutia vel'konemeckej národnozjednocovacej ideológie. Z hladiska komparácie slovenského a juhoslovanského národného hnutia vo vývine revolúcie je dôležitá prudká polemika medzi Slovákmi a južnými Slovanmi. Juhoslovania - predovšetkým Chorváti, požadovali, aby Slováci deklarovali nezávislost' Slovenska v Uhorsku, no slovenská delegácia zotrvávala na platforme integrity Uhorska a možnej dohody s mad’arskou vládou. Štúr, Hurban a ich spoločníci rozvíjajú $\mathrm{v}$ tomto období v slovanskom hnutí slovensko-chorvátsky postup voči Madarom. Na spoločnú koordináciu sa vytvoril spoločný slovensko-chorvátsky výbor (Štúr, Hurban, Gaj, Strossmayer) a tí rokovali o podpore s Poliakmi. Nasledujúce mesiace po slovanskom sneme v Prahe, sa slovenská politická reprezentácia utiekala k južným Slovanom. „Tak hlavnou nádejou Slovákov zostali Chorváti ako najsilnejší opozičný faktor. Do Záhrebu, resp. k Srbom, ktorí už 13. - 15. mája na cirkevno-autonómnom sneme v Sriemskych Karloviciach vyhlásili autonómnu Vojvodinu a jej spojenie s Chorvátskom, sa teda utiekali nielen emigrovaní slovenskí učitelia, ale i nádeje národného hnutia na Slovensku. Hovoríme o chorvátskej etape slovenského národnooslobodzovacieho zápasu v revolúcii“ (Krajčovič 2010, 41).

Odlišné predstavy nemad’arských národov o koncepcii a usporiadaní pomerov v Uhorsku, presadzovanie madarčiny dali za vznik odklonu politických hnutí nemadarských národov od liberálnych politikov. To malo za príčinu aj odmietanie návrhov, ktoré by pomohli aj nemadarskému obyvatelstvu. Viedenská politika pod prizmou a záujmom zachovania celistvosti monarchie sledovala tieto národnostné trenice a neraz vytvárala falošný dojem nemad’arským politickým predstavitelom o záujme Viedne o ich problémy.

${ }_{14}$ „Za cijelo to vrijeme, dok se Hrvatska zanosila ilirstvom, u susjednim slavenskim zemljama, s kojima se pri tome računalo u ilirskom kolu, ova ideja nije stekla pristaša. Od Slovenaca pridružio joj se jedino Stanko Vraz, zbog čega su ga njegovi sunarodnjaci otvoreno osudili, pa i sam Prešeren. A od viđenijih Srba uz ilirstvo nije pristao nitko."

15 Austroslavizmus - ideové hnutie v Rakúskom cisárstve, kde sa kládol dôraz na zrovnoprávnenie slovanských národov. 
Zásadným momentom reformného snemu bolo prijatie zákona, ktorý umožňoval aj osobám nešlachtického pôvodu zastávat všetky krajinské úrady a držbu šlachtického statku. Dôsledky postupnej madarizácie sa odrazili na vzţahoch s nemadarskými národmi. Chorvátska politická reprezentácia v roku 1843 koordinovala svoj postoj v užšom spojení s vládou vo Viedni. Ozbrojené konflikty prepukli v Záhrebe dňa 9. decembra 1843, prišlo k stretu národnej a uhorskej strany, ktoré si vyžiadali obete. Do roku 1845 sa postupne chorvátska politická reprezentácia rozišla s uhorskou reprezentáciou (Kónya 2014, 539).

15. marca 1848 sa zišla skupina mladých radikálnych demokratov v kaviarni Plivax. Medzi nimi boli aj Sándor Petőfi, Mór Jókai a József Irínyi. Zakrátko sa na peštianskom námestí zhromaždilo 20 tisíc ludí a vypočuli si revolučnú báseň Nemzeti dal. Situácia sa postupne radikalizovala a revolúcia sa rozšírila do ostatných častí Uhorského královstva.

Právnu kodifikáciu revolučných zákonov poskytli Uhorskej vláde tzv. Aprílové zákony. Podla Kovácsa „zákony potvrdzovali nové právne usporiadanie Uhorska, zrušenie Uhorskej dvorskej kancelárie, Uhorského miestodržitela (palatína) a zrušenie poddanstva. Práve tieto inštitúcie predstavovali obraz absolutistickej Viedenskej vlády“ (Kovács 2002, 69). Avšak nejednoznačnosț Aprílových zákonov v otázkach zahraničnej politiky, armády a štátneho rozpočtu vyvolávala nespokojnost’ v politickej reprezentácii Uhorska. Zásadným problémom bol vztah Uhorska k Chorvátsku-Slavónsku. Revolučné udalosti v habsburskej monarchii tiež vyvolali sériu udalostí v Chorvátsku. Zvýraznenie národných požiadaviek z marca 1848 a návrh ústavného zákona uhorského parlamentu, ktorý predpokladá centralizovaný štát $s$ mad’arčinou ako oficiálnym jazykom, v ktorom by sa Slavónia stala neoddelitel'nou súčastou Uhorska, a Chorvátsku by zostala provinčná autonómia, spôsobila odpor chorvátskych politikov. Predstavitelia národnej strany, povzbudení marcovými revolučnými udalostami vo Viedni a pádu Metternicha, nemohli zvolat chorvátsky parlament, pretvorili zasadanie záhrebského zasadnutia do Národného zhromaždenia. ${ }^{16}$ Uhorskí politici následne dovolili používat’ v častiach krajiny, ktoré nie sú integrálnou súčastou Uhorska (Chorvátsko-Slavónsko, Fiume) materinský jazyk. Situáciu počas revolúcie nám ilustruje aj chorvátsky historik Tomislav Markus, ked’ píše: „V marci 1848 sa vo Viedni objavili nepokoje a bol zvrhnutý kancelár Metternich, symbol predvojnového poriadku. Uhorská elita využila slabost̉ viedenského dvora a krála vydierali a chceli dosiahnut vel'ké politické ústupky, čo dalo Uhorsku status de facto nezávislého štátu so zahraničnými, vojenskými a finančnými záležitostami. Čoskoro najväčším problémom chorvátskeho politického hnutia sa stal konflikt s novou mad’arskou vládou, ktorá mala formálnu legitimitu. Chorvátska elita sa nemohla spoliehat na obmedzenú podporu viedenského dvora, ktorý dočasne stratil akýkolvek vplyv v oblasti Transylvánie, okrem niektorých jednotiek cisárskej armády. Mnohé dokumenty súvisiace $s$ vtedajším chorvátskym hnutím odsudzujú ešte viac ako predtým politiku madarizácie a nútenie mad’arského jazyka Slovákom, Rumunom a Srbom“17.

16 Dostupné online: http://www.enciklopedija.hr/natuknica.aspx?id=52630 - Revolucionarna zbivanja u Habsburškoj Monarhiji potaknula su i niz događaja u Hrvatskoj. Isticanje madž. nacionalnih zahtjeva u ožujku 1848. te prijedlog ustavnoga zakona Ugarskoga sabora, koji je predviđao centraliziranu državu s madžarskim kao službenim jezikom, u kojoj bi Slavonija postala sastavnim dijelom Ugarske, a užoj Hrvatskoj ostala bi pokrajinska autonomija, izazvao je otpor hrv. političara. Tada su predstavnici Narodne stranke, potaknuti ožujskim prevratom u Beču i Metternichovim padom, a u nemogućnosti saziva Hrvatskoga sabora, pretvorili Zagrebačku skupštinu u Narodnu skupštinu.

17 „U ožujku 1848 došlo je do nereda u Beču i pada omraženog kancelara Metternicha, simbola predožujskog poretka. Mađarska elita iskoristila je slabost bečkog dvora i od kralja iznudila velike političke ustupke, koje su Mađarskoj dale status de facto samostalne države, s resorima vanjskoh, vojnih i financijskih poslova. Ubrzo najveći problem hrvatskog političkog pokreta postao sukob s novom mađarskom vladom, koja je imala formalni legitimitet. Hrvatska elita više nije mogla kao prije računati na ongraničenu podršku bečkog dvora, koji je privremeno izgubio svaki utjecaj u zemljama Translajtanije, osim donekle 
Otázka národností ostávala dlhodobo neriešená, aj ked’ Aprílové zákony určovali rovnost̉ všetkých obyvatel'ov krajiny bez zretela na ich národnú príslušnost', Kossuth a ostatní politici ostávali na svojich predchádzajúcich pozíciách a zastávali názor jediného politického národa. Tieto postoje viedli nemadarské národnosti k rozkolu a rozídeniu sa s madarskou reprezentáciou a hladali oporu vo Viedenskej vláde. „Na druhej strane sa však vel'ká čast’ príslušníkov nemad’arských národov rozhodne postavila za novú vládu v Pešti a zúčastnila sa nastávajúcich vojnových udalostí (najmä Nemci, okrem sedmohradských Sasov, Rusíni a Slováci, menej Rumuni)“ (Kónya 2014, 553).

Jar 1848 sa niesla v znamení vystúpenia národných politických predstavitelov, ktorí nesúhlasili s politikou Pešti. Predovšetkým Chorváti, Srbi, Slováci, Rumuni a sedmohradskí Sasi. O problémoch medzi nemadarskými národnostami a mad’arskými politikmi nám podáva informáciu srbský spisovatel', historik a diplomat Andra Gavrilović: „V apríli toho istého roku (1848) poslalo mesto Nový Sad delegáciu do Prešporka, aby predložili stažnosti a želania srbského ludu v Uhorsku pred madarským parlamentom. Medzi poslancami bol aj mladý Stratimirović. V Prešporku u Kossutha, starí členovia delegácie ani neupriamili na hlavnú vec, ale Stratimirovićc ${ }^{18}$ mal plán, vzal si slovo a energicky vyhlásil, že Srbov by upokojili iba vtedy, ked’ dosiahnu autonómiu. Kossuth nahnevane zakričal: „To sú zradné slová, ale ked je tak, potom budeme diskutovat mečom! "Stratimirović pyšne dokončí: „Srbi sa toho neboja! "19 Požiadavky zo 6. marca v Budíne sformoval Isidor Nikolić ${ }^{20}$ : „Srbi uznávajú mad’arskú národnost’ a diplomatickú dôstojnost’ mad’arského jazyka v Mad’arsku, ale vyžadujú, aby ich národnost' bola uznaná a slobodne používala svoj jazyk vo všetkých svojich dielach a vo svojich zákonoch. “21 Na rozdiel od Rumunov, Srbi v tom čase disponovali značným potencionálom v oblasti hospodárstva a privilégiami v obchodnej sfére. 27. marca 1848 sa v Novom Sade uskutočnilo srbské národné zhromaždenie, kde sa predložila požiadavka na uznanie srbského národa s požiadavkou na vlastné autonómne územie Спркска Војводина (Srbská Vojvodina). 13. - 15. mája bola v Karloviciach vyhlásená autonómia a ozbrojené povstanie voči uhorskej vláde, čo v júni vyústilo do občianskej vojny.

Podobná situácia eskalovala do ozbrojeného stretu aj v Chorvátsku. Panovník vymenoval Josipa Jelačića za bána 22. marca 1848, o tri dni neskôr záhrebský sobor ${ }^{22}$ spísal požiadavky panovníkovi, v ktorých požadovali zjednotenie Chorvátska, Slavónska, Dalmácie, uhorského pobrežia a vojenskej hranici v Slavónsku do celku známeho ako Trojjedina kraljevina ${ }^{23}$. V prosbopise panovníkovi boli taktiež obsiahnuté požiadavky ako vymenovanie vlastnej vlády, zavedenie jediného chorvátskeho úradného jazyka, ktorý by sa využíval pre komunikáciu i s celouhorskými

u jedinicama carske vojske. Mnogi dokumenti vezani uz tadašnji hrvatski pokret osuđuju, još više nego ranije, politiku mađarizacije i nametanja mađarskog jezika Slovacima, Rumunjima i Srbima. “Dostupné online na https://hrcak.srce.hr/file/46058.

18 Đorđe Stratimirović - velitel’ srbských vojsk v revolúcii 1848/1849.

19 Ту га је затекао велики народни покрет 1848. године. У априлу те године варош Нови Сад посла депутацију у Пожун да пред угарски сабор изнесе жалбе и жеље српскога народа у Угарској. Међу депутатима бејаше и млади Стратимировић. У Пожуну код Кошута старији чланови депутације не удараху гласом на главну ствар, али Стратимировић плану, узе реч и енергично изјави да ће се Срби умирити само онда кад добију своју аутономију. Кошут љутито викну: „То су речи издајничке, али кад је тако онда ћемо сабљом расправљати!“ Стратимировић поносито заврши: „Србин се тога не боји!“

20 Isidor Nikolić - srbský politik.

21 „Srblji priznaju mađarsku narodnost i diplomatičko dostoinstvo mađarskog jezika u Ungariji, ali zahtevaju da se njiova narodnost prizna i slobodno upotrebljavanje jezika njinog u svim njenim delima i savetovanjima zakonom utvrdi."

22 parlament

23 Trojjediné královstvo 
úradmi. Chorváti sa rozchádzali s politickou reprezentáciou Uhorska aj v oblasti integrity krajiny a požadovali pripojenie k Rakúskej časti (Kónya 2014, 553). Postoj Chorvátov asi najlepšie vystihuje prehlásenie, ktoré bolo v septembri 1848 poslané do Pešti: „Chceme rovnost' a rovnost' všetkých národov a národností, ktoré žijú pod korunou Uhorska. Uhorské ministerstvo sa odvtedy domnieva, že nemôže súhlasit’ sýmito zmluvami, je našou ctou a povinnostou nás, aby sme sa pokúsili dohodnút alebo budeme bojovat zbraňami. “24 Po vypuknutí ozbrojenej revolúcie vo Viedni sa vydáva Jelačić s armádou proti potlačeniu revolúcie s úmyslom, že napomáha myšlienke federalizácie monarchie. V tomto období sa realizuje aj kooperácia slovensko-chorvátskych ozbrojených zborov, vyjadruje sa obojstranná podpora a spolupráca. Ako príklad uvádzame prepis Jelačićovho listu adresovaného Slovákom: „Slovačka Bratjo! Dočim ja s vojskom hrvatsko-slavonskom iz Ugarske prot Beču se obratih: učinio sam to iz obsvédočenja, da nepriatelj slavjanski glavu svoju u Beču dižući, u Ugarskoj pobědih se nedade. I kad ja čelovitost Austrie u svima mojima dělih tražim: to činím zato, jer je Austria u Slavjanstvu: a Slavjanstvo U Austrii sitno. Vas, Bratjo! uputjujem, da se na domorodca našeg Gjenerala Šimunića, koji iz Galicie ide obratite, i kod njeg pravo, zaštitu i pomoć potražite u koju Vas kod njega ovim priporučujem. U glavnom stanu vojske dvv.stav. Zvölfazingu 22 Listopada 1848 Primite Pozdrav moj Jellačić Ban. “25

Z listu možno vydedukovat, že Chorváti pokladali Slovákov za prirodzených spojencov v rámci národnostnej politiky uhorskej vlády. Uhorská revolúcia sa nevyvíjala podla predstáv mad’arských politikov a revolúcia bola v lete 1849 potlačená pomocou ruských vojsk. Cisársky dvor vo Viedni sa následne snažil o pacifikáciu jednotlivých národnostných hnutí. Slováci a Chorváti po revolúcii nedosiahli väčšie ústupky od cisárskeho dvora vo Viedni, a tak v podstate sa stav vecí vrátil do čias pred revolúciou. Treba však pripomenút, že v roku 1867 došlo k rakúsko-uhorskému vyrovnaniu, kedy sa de facto Uhorsko stalo rovnocenným partnerom voči Rakúsku a obe krajiny spájala osoba panovníka, armáda a zahraničná politika. Interným vyrovnaním v Uhorsku získalo Chorvátsko na základe tzv. chorvátsko-uhorského vyrovnania (1868) čiastočnú vnútornú, cirkevnú, školskú a súdnu autonómiu v rámci (velkého) Uhorska. Ján Jankovič napísal v úvode svojej vedeckej práce Chorvátska literatúra $v$ slovenskej literatúre I. myšlienku, ktorá vystihuje velmi dobré vzájomné vzt̉ahy Slovákov a Chorvátov: „Tradičné živé vedomie našej genetickej blízkosti, kolektívnych aj individuálnych prejavov spolupatričnosti si naše národy neustále uchovávajú. Slováci, a iste aj Chorváti, pocitujú záväzky tak voči minulosti a súčasnosti, ako aj voči budúcnosti. Tradíciu našich vztahov vždy výrazne posilňovala principiálna podobnost’ historických osudov našich etník." Vedomie blízkosti našich národov a spolupatričnosṫ v náročných historických okamžikoch pretrvali storočia, preto aj záujem o chorvátsku kultúru a jazyk pretrváva v čase globalizácie a integrácie národných štátov do európskych štruktúr.

\section{SUMMARY}

Relations between the Slovaks and the Croats show a close connection in the field of culture, military cooperation and common national interests. The Slovak national movement was fragile and sought suitable allies for its political and national goals. Unlike the cooperation from the Czech environment, the Croatian and South Slavic environment was more similar to that of the Slovaks in Hungary. With certain differences, both movements have been complemented and

24 Mi hoćemo jednakost i ravnopravnost svih naroda i narodnosti, što žive pod krunom ugarskom. Pošto dakle ministarstvo mađarsko misli, da ne može pristati na te pogodbe zato nam nalaže čast i dužnost, da pokušamo zadnje, pa da se latimo oružja.

25 Cit. Slovenská národná knižnica (SNK) - Archív literatúry a umenia Martin. Korešpondencia Jozef Jelačić - List Slovákom, sg. 29 I 37. 
cooperated in many areas. Failure to meet the ambitions of the Slovaks and Croats resulted in the decades-long after the revolution, when both nations fought for survival. These relationships are to be found in our Slovak cultural context. The contribution also aims to point out the Croat orientation of Slovak national representatives and seeks to raise issues for further research in the field of Slovak and Croatian relations. Nearly thousands of years of history, the similarity of languages and cultures show us the period of the first half of the 19th century, as should the current cooperation of both nations.

\title{
LITERATÚRA
}

Bednárová, Marcela, 2012. Symboly a mýty chorvátskeho národného hnutia. Bratislava: Veda.

Butorac, Josip, 1929 - 1930. Patriotske veze hrvatskog i slovačkog djaštva u prošlosti. In: Luć, 25, $186-188$.

Гавриловић, Андра, 2008. Знаменити Срби ХІХ века. Београд: Научна КМД.

Jankovič, Ján, 1997. Chorvátska literatúra v slovenskej literatúre I.. Bratislava: SAV.

Jelčić, Dubravko, 2002. Hrvatski književni romantizam. Zagreb: Školska knjiga.

Klátik, Zlatko, 1965. Štúrovci a Juhoslovania. Bratislava: SAV.

Kollár, Ján, 2009. Dielo. Bratislava: Kaligram.

Kónya, Peter, 2014. Dejiny Uhorska. Bratislava: Citadella.

Krajčovič, Milan, 2010. Slovenské národné hnutie v medzinárodnom kontexte. Bratislava: SAP.

Kučera, Matúš, 2013. Slováci a Chorváti (Historické a kultúrne vzṫahy). Bratislava: Post Scriptum. Moguš, Milan, 2009. Povijest hrvatskoga književnoga jezika. Zagreb: Nakladni zavod Globus.

\section{KONTAKT}

\author{
Mgr. Tomáš Móri \\ Ústav stredoeurópskych jazykov a kultúr \\ Fakulta stredoeurópskych štúdií UKF v Nitre \\ Dražovská 4 \\ 94974 Nitra \\ Slovenská republika \\ tomas.mori23@gmail.com
}

